\title{
PENGUATAN SOLIDARITAS SOSIAL KEMASYARAKAT DALAM RANGKA PEMBENTUKAN SATUAN TUGAS BENCANA DI DESA PAMONG KECAMATAN CIRUAS KABUPATEN SERANG
}

\author{
Abdul Apip ${ }^{1}$, Rahmawati ${ }^{2}$ \\ ${ }^{1,2}$ Universitas Sultan Ageng Tirtayasa, J1 Raya Jakarta Km 4 Pakupatan Serang, Banten, Indonesia \\ ${ }^{2}$ Universitas Sultan Ageng Tirtayasa, Jl Raya Jakarta Km 4 Pakupatan Serang, Banten, Inidonesia \\ Email: apip.abdul@untirta.ac.id
}

\begin{abstract}
Social solidarity is a relationship between individuals or groups based on moral feelings shared and strengthened by shared emotional experiences. Solidarity can be formed because of the same race, ethnicity or the same feelings. Social solidarity is divided into two, namely mechanical solidarity that is identical to rural communities and organic solidarity that is identical to the culture of modern society. The Covid-19 pandemic that has spread throughout the world, including Indonesia, has had a huge impact on people's lives, both from an economic, social and cultural perspective. Pamong Village is one of the villages where most of the men work as migrant workers in Jakarta. Work in the service sector as a shop assistant in trade centers such as Mangga Dua, Glodog and Tanabang, as a convention worker, as an online driver. With the Covid-19 pandemic, most workers from Pamong Village were also sent home and laid off. The problem faced by the Pamong Village community is the increasing number of families without income / vulnerable groups of people who are poor. The research objective was to find out how the social solidarity of the Pamong Village community in the framework of forming a disaster task force. The method used is qualitative with a survey approach. The research informants were village officials and the Pamong village community. The results of the activity show that the social solidarity that has been built in Pamong Village is still close, where the form of routine activities carried out is weekly recitation for both men and recitation for mothers. In addition, social solidarity is still carried out by the plerek system or the collection of rice or money that is freely collected by young people and used for social funds or compensation for families affected by disaster, illness or death, including when there are families experiencing economic difficulties. The Head of the Pamong Village also activated bi-weekly community service activities which were carried out in rotation in each village. To build togetherness among village officials, the village head routinely routines Friday or clean Friday activities on the third week of each month. The results showed that efforts to build and strengthen social solidarity in a region really depend on the leadership figure of the village head in mobilizing village officials and communities to work together in overcoming social problems that occur in the region. The impact of the research shows that the character of the village community which is thick with the spirit of mutual cooperation and togetherness can be revived if the village head is closer and understands the character of the community.
\end{abstract}

Keywords: Social Solidarity: Society; Covid-19 Pandemic.

\begin{abstract}
ABSTRAK
Solidaritas sosial merupakan hubungan antar individu atau kelompok dengan dasar perasaan moral yang dianut bersama dan dikuatkan oleh pengalaman emosional bersama. Solidaritas dapat terbentuk karena kesamaan ras, suku atau adanya perasaan yang sama. Solidaritas sosial terbagi dua yaitu solidaritas mekanik yang identic dengan masyarakat pedesaan dan solidaritas organic yang identic dengan budaya masyarakat modern. Adanya pandemic Covid-19 yang mewabah di seluruh dunia termasuk Indonesia, menyebabkan dampak yang sangat besar bagi kehidupan masyarakat baik dari sisi ekonomi, sosial dan budaya. Desa Pamong merupakan salah satu desa dimana sebagian besar kaum laki-laki bekerja sebagai buruh migran di Jakarta. Bekerja di sector jasa sebagai pelayan toko di pusat perdagangan seperti Mangga Dua, Glodog dan Tanabang, sebagai buruh konvensi, sebagai pengemudi online. Dengan adanya
\end{abstract}


pandemic Covid-19 ini, sebagian besar pekerja dari Desa Pamong juga dirumahkan dan diberhentikan. Permasalahan yang dihadapi oleh masyarakat Desa Pamong adalah semakin meningkatnya jumlah keluarga yang tidak memiliki pendapatan/kelompok masyaraat rentan miskin. Tujuan penelitian adalah untuk mengetahui bagaimana solidaritas social masyarakat Desa Pamong dalam rangka pembentukan gugus tugas bencana. Metode yang digunakan adalah kualitatif dengan pendekatan survey. Informan penelitian adalah perangkat desa dan masyarakat desa Pamong. Hasil kegiatan diketahui bahwa Solidaritas sosial kemasyarakatan yang terbangun di Desa Pamong masih erat, dimana bentuk kegiatan yang rutin dilakukan adalah pengajian mingguan baik untuk laki-laki dan pengajian ibu-ibu. Di samping itu pula solidaritas sosial yang tetap dilakukan system plerek atau pengumpulan beras atau uang seikhlasnya yang dikumpulkan oleh pemuda-pemuda dan digunakan untuk dana sosial ataupun santunan bagi keluarga yang terkena musibah, sakit atau meninggal dunia termasuk juga ketika ada keluarga yang mengalami kesulitan ekonomi. Kepala Desa Pamong juga mengaktifkan kegiatan kerja bakti dua mingguan yang dilakukan secara bergiliran pada tiap kampung. Untuk membangun kebersamaan di antara perangkat desa, kepala desa merutinkan kegiatan jumasih atau jumat bersih pada minggu ketiga setiap bulannya. Hasil penelitian menunjukkan bahwa upaya membangun dan memperkuat solidaritas social kemasyarakat di suatu wilayah sangat bergantung bagaimana figure kepemimpinan kepala desa dalam menggerakan perangkat desa dan masyarakat untuk bekerja sama dalam mengatasi permasalahan social yang terjadi di wilayahnya. Dampak penelitian diketahui bahwa karakter masyarakat desa yang kental dengan semangat gotong royong dan kebersamaan dapat dimunculkan kembali jika kepala desa lebih dekat dan memahami karakter masyarakatnya.

Kata Kunci: Solidaritas Sosial; Masyarakat; Pandemik Covid-19.

\section{PENDAHULUAN}

Saat ini dunia sedang menghadapi masalah kesehatan yang luar biasa yaitu adanya pandemik atau wabah virus Corona. Virus Corona atau disebut Covid19 merupakan virus yang pertama kali ditemukan menyerang manusia di daerah Wuhan China. Di Indonesia sendiri, wabah virus corona telah ditetapkan oleh pemerintah sebagai bencana nasional berdasarkan hasil Rapat Koordinasi yang dipimpin oleh Menteri Koordinator PMK, Menteri Kesehatan, Menteri Luar Negeri, Menteri Sosial dan Badan Nasional Penanggulangan Bencana atau BNPB pada tanggal 28 Januari 2020. Yang kemudian berdasarkan Peraturan Presiden Nomor 17 Tahun 2018 pasal 8 menyebutkan bahwa status keadaan bencana diperlukan agar BNPB dapat melaksanakan operasi darurat baik di tingkat nasional, provinsi maupun kabupaten/kota. Untuk mempercepat penangannya, Presiden RI mengeluarkan Keppres Nomor 7 Tahun 2020 tentang Gugus Tugas Percepatan Penanganan Coronavirus Disease (Covid-19) menunjuk BNPB sebagai koordinator.

Badan Nasional Penanggulangan Bencana kemudian menerbitkan Surat Keputusan Kepala BNPB Nomor 9. A tahun 2020 tentang Penetapan Status keadaan tertentu darurat wabah penyakit akibat virus Corona di Indonesia selama 32 hari, kemudian diperpanjang dengan Surat Keputusan Kepala BNPB Nomor 13.S Tahun 2020 tentang Perpanjangan Status Keadaan Tertentu Darurat Bencana Wabah Penyakit akibat virus Corona di Indonesia yang berlaku selama 91 hari terhitung sejak tanggal 29 Februari - 29 Mei 2020. Pada tanggal 23 April 2020 jumlah kasus Covid-19 yang positif sebanyak 8.211, meninggal 689 dan sembuh 1.002 (www.bnpb.go.id). 
Semakin meningkatnya jumlah kasus penderita virus corona di Indonesia membuat pemerintah menetapkan kebijakan Pembatasan Sosial Berskala Besar (PSBB) di beberapa daerah, terutama di Kota Jakarta sebagai episentrum penyebaran Covid-19, Kota Depok, Kota Tangerang, Kabupaten Tangerang, Kota Bogor juga telah menetapkan status PSBB. Tujuan dari PSBB adalah menghentikan atau mengurangi penyebaran virus corona. Ketidakpastian akan waktu berakhir atau masa pandemic Covid-19 ini menimbulkan banyak ketidakpastian dan kekhawatiran di masyarakat. Termasuk penerapan PSBB menimbulkan dampak ekonomi bagi pengusaha dan masyarakat. Beberapa dampak yang ditimbulkan akibat virus corona ini adalah pemberhentian karyawan, usaha kecil yang gulung tikar, sekolah diliburkan, tingkat hunian hotel menurun drastic termasuk dampak pada sector lain seperti perdagangan dan jasa.

Berdasarkan hasil diskusi yang dilakukan oleh Fisip UGM dengan tema Penguatan Solidaritas Sosial di tengah Krisis Covid-19 pada 13 April 2019 disimpulkan bahwa Covid-19 tidak hanya menimbulkan risiko klinis pada manusia namun juga menghadirkan berbagai konsekuensi social dan ekonomi yang tidak sepenuhnya sanggup ditopang oleh negara. Pada level kognisi social, lahirnya kesadaran dan inisiatif masyarakat untuk ikut berperan dalam menangani covid-19. Masyarakat belajar pengetahuan baru terkait pandemi covid-19 seperti karakter virus, pencegahan, penanganan serta mekanisme dampaknya. Pada level individu, masyarakat memiliki kesadaran higienitas dan Kesehatan diri maupun lingkungan dan secara lebih artikulatif saling mengingkatkan. Secara komunal, inisiasi pertahan diri dibangun di berbagai tingkatan wilayah, termasuk di kampung-kampung. Tumbuhnya solidaritas social di kalangan akar rumput masyarakat Indonesia berasal pada karakter masyarakat local Indonesia yang kental dengan semangat gotong royong dan semangat komunalitas.

Hasil diskusi juga menyampaikan beberapa hal terkait bagaimana upaya memperkuat solidaritas social di level akar rumput agar berjalan produktif dan berumur Panjang, yaitu 1) memperkuat ketahanan keluarga sebagai garda terdepan dalam upaya menjaga imunitas dan kedisiplinan jaga jarak ; 2) berpijak pada informasi yang benar tentang covid-19 untuk menghindari diskriminasi dan stigmatisasi; 3) menyesuaikan aksi-kasi bantuan dengan kemampuan dan potensi sumber daya yang tersedia; 4) menggalang dana dari masyarakat untuk membiayai aksi-aksi digital melawan covid-19, dan 5) memberikan sumbangan dana dan bahan makanan pokok bagi pekerja atau buruh yang mengalami PHK maupun kelompok rentan dan ekonomi lemah lainnya.

Desa Pamong merupakan salah satu desa di Kecamatan Ciruas dengan potensi ekonomi di sector pertanian. Akan tetapi mayoritas penduduknya bekerja sebagai buruh migran di Kota Jakarta, terutama bekerja sebagai buruh pabrik, usaha kecil termasuk konveksi. Berdasarkan tingkat pendidikan masyarakat usia produktif, sebagian besar tamatan sekolah menengah 
pertama yang kemudian mengadu nasib bekerja ke Jakarta. Sementara untuk perempuan atau ibu rumah tangga, bekerja membantu suami bekerja sebagai asisten rumah tangga di sekitaran perumahan yang dekat dengan Desa Pamong. Semenjak adanya pandemic corona ini banyak warga Pamong yang bekerja di Jakarta kehilangan pekerjaan dan di PHK oleh perusahaannya. Dengan kondisi sebagian besar warga desa Pamong bekerja di Jakarta yang merupakan episentrum penyebaran Covid-19, yang dikhawatirkan adalah para pekerja tersebut berperan sebagai carier atau pembawa virus, bahkan telah teridentifkasi satu orang warga Desa Pamong berstatus ODP setelah pulang dari Jakarta bekerja sebagai buruh konveksi. Akibat adanya wabah corona ini, praktis banyak keluarga di Desa Pamong yang tidak memiliki pendapatan karena kepala keluarga mendapatkan PHK dan para perempuan juga diberentikan sebagai ART.

\section{METODE}

Metode yang digunakan dalam kegiatan pengabdian ini antara lain survey dan penyuluhan. Metode survey dilakukan pada awal kegiatan pengabdian kepada masyrakat akan dilakukan. Dari kegiatan survey ini tim pengabdian mendapatkan informasi awal tentang desa, persoalan solidaritas sosial yang terjadi di masyarakat serta tata kelola pemerintahan yang selama ini berjalan. Data penelitian menggunakan data primer yang bersumber dari pemerintah desa dan masyarakat yang hadir dalam kegiatan pengabdian kepada masyarakat. Metode penyuluhan dilakukan setelah tim pengabdian melakukan identifikasi urgensi materi atau tema penyuluhan yang akan diberikan kepada masyarakat dan pemerintahan desa berkaitan dengan tema besar pengabdian.

\section{HASIL DAN PEMBAHASAN}

Desa Pamong merupakan salah satu desa di Kecamatan Ciruas yang berbatasan dengan Desa Cigelam di bagian Utara, berbatasan dengan Desa Teritih di bagian selatan, dengan Desa Kepandean di bagian timur dan berbatasan dengan Desa Bendungan di bagian Barat. Memiliki luas wilayah pemukiman sebesar 3,5 hektar persegi dengan luas area persawahan sebanyak 208.879 hektar dan terdapat 7000 meter persegi digunakan untuk sarana prasarana. Sebagai sebuah desa, Desa Pamong juga memiliki tanah bengkok seluas 5 hektar, lapangan olah raga seluas 4000 meter persegi, luas untuk bangunan perkantoran pemerintahan 1500 meter persegi.

Potensi utama Desa Pamong adalah sektor pertanian dengan hasil panen padi mencapai 5.5 ton per hektar. Jumlah penduduk Desa Pamong tahun 2019 sebanyak 4210 jiwa dengan jenis kelamin laki-laki sebanyak 2137 orang dan sebanyak 2073 orang berjenis kelamin perempuan. berikut ini komposisi penduduk dari mata pencaharian. 
Tabel 1. Karakteristik Masyarakat menurut Lapangan Pekerjaan

\begin{tabular}{|c|c|c|}
\hline Jenis Pekerjaan & Laki-laki & Perempuan \\
\hline Petani & 147 & 11 \\
\hline Buruh Tani & 617 & 165 \\
\hline PNS & 5 & 2 \\
\hline Pedagang keliling & 9 & 14 \\
\hline Bidan swasta & - & 1 \\
\hline TNI/Polri & 3 & - \\
\hline Asisten rumah tangga & - & 50 \\
\hline Wiraswasta & 31 & - \\
\hline
\end{tabular}

(Monografi Desa Pamong, 2019)

Berdasarkan tabel diatas diketahui bahwa jumlah buruh tani lebih besar dibandingkan dengan petani sendiri. Artinya, luas lahan pertanian yang berada di Desa Pamong bukan merupakan lahan pertanian milik pribadi. Kepemilikan sawah sudah banyak beralih kepada orang lain di luar Desa Pamong sehingga pemilik lahan sebelumnya berstatus sebagai buruh tani.

Tabel 2. Komposisi Penduduk menurut Struktur Penduduk

\begin{tabular}{|l|c|c|}
\hline \multicolumn{1}{|c|}{ Usia } & Laki-laki & Perempuan \\
\hline $0-6$ tahun & 370 & 275 \\
\hline $7-18$ tahun & 257 & 214 \\
\hline $18-56$ tahun bekerja & 1190 & 217 \\
\hline $18-56$ tahun tidak bekerja & 188 & 940 \\
\hline Lebih dari 56 tahun & 468 & 641 \\
\hline
\end{tabular}

(Monografi Desa Pamong, 2019)

Merujuk pada tabel diatas pada usia 18 - 56 tahun yang bekerja dengan jenis pekerjaan mayoritas sebagai buruh tani.

Tabel 3. Komposisi Penduduk Bekerja menurut Tingkat Pendidikan

\begin{tabular}{|l|c|c|}
\hline Usia $18-56$ tahun bekerja & Laki-laki & Perempuan \\
\hline Buta huruf & 213 & 187 \\
\hline Tidak tamat SD & 173 & 113 \\
\hline Tamat SD & 1149 & 1157 \\
\hline SMP & 195 & 147 \\
\hline SMA & 43 & 17 \\
\hline Perguruan tinggi & 7 & 4 \\
\hline
\end{tabular}

(Monografi Desa Pamong, 2019)

Berdasarkan tabel diatas, diketahui bahwa dari kualitas pendidikan, angkatan kerja di Desa Pamong termasuk kategori rendah yaitu hanya tamat Sekolah Dasar sebanyak 2306, diikuti dengan penduduk yang masih buta huruf sebanyak 400 orang. Berdasarkan hasil 
wawancara dengan perangkat desa diketahui bahwa penduduk desa pamong yang bekerja migran ke Jakarta rata-rata pendidikan SD, SMP dan tidak tamat SD. Sebagian besar bekerja sebagai buruh di pabrik konvenksi, pertokoan dan sector jasa lainnya. Berdasarkan jumlah anggota keluarga, mayoritas penduduk Desa Pamong yang kepala keluarganya bekerja ke Jakarta memiliki jumlah anak sebanyak 3-4 orang.

Pada bulan November tahun 2019 Desa Pamong salah satu desa yang menyelenggarakan pemilihan kepala desa secara langsung. Suksesi kepemimpinan berjalan dengan lancar dan pemerintah desa yang berjalan saat ini dengan kepala desa pemenang pilkades beserta jajarannya baru berjalan delapan bulan. Selain sekretaris desa, semua perangkat desa Pamong berstatus pegawai baru. Jumlah perangkat desa sebanyak 7 orang dengan 2 orang perempuan dan 5 orang laki-laki. Dari tingkat pendidikan 6 orang tamatan SLTA dan 1 orang pendidikan sarjana. Sementara itu Badan Permusyawaratan Desa (BPD) terdiri dari 7 orang laki-laki dan 1 orang perempuan. tugas BPD merupakan dewan penasihat memberikan evaluasi dan melakukan pengawasan pelaksanaan kegiatan pemerintahan dan pemberian pelayanan kepada masyarakat.

Pada saat dilakukan survey awal pengabdian diketahui bahwa Desa Pamong merupakan salah satu desa yang baru saja melakukan pemilihan kepala desa langsung dan kepala desa beserta jajarannya baru melaksanakan pemerintahan selama delapan bulan. Oleh karena itu, dalam kegiatan penyuluhan materi yang disampaikan adalah gaya kepemimpinan desa dalam meningkatkan solidaritas sosial kemasyarakat. Kegiatan dihadiri oleh perangkat desa, ketua dan sekretaris BPD serta masyarakat Desa Pamong

Durkheim seorang sosiolog menyampaikan bahwa masyarakat terbentuk atas interaksi atau relasi yang terjadi antara individu dan masyarakat. Durkheim juga mengkonseptualisasikan masyarakat dalam hal norma-normanya atau jenis-jenis integrasi sosial ( yaitu cara individu secara sosiologis berhubungan dengan struktur sosial melalui fakta-fakta sosial ). Salah satu kajian utamanya adalah semacam sifat-sifat solidaritas sosial dari masyarakat tertentu. Durkheim melacak perkembangan relasi modern di antara para individu dan masyarakat. Secara khusus, Durkheim ingin menggunakan ilmu sosiologinya yang baru untuk memeriksa apa yang oleh banyak orang pada masa itu telah dilihat sebagai krisis moralitas modern.

Durkheim mengamati bahwa peningkatan sistem pembagian kerja tersebut berimplikasi pada perubahan tipe solidaritas sosialnya. Ia menjelaskan adanya dua tipe solidaritas sosial yang dikaitkan dengan tingkat pembagian kerja dalam masyarakat. Pada masyarakat dengan system pembagian kerja yang rendah, akan menghasilkan tipe solidaritas mekanik, sedangkan pada masyarakat dengan pembagian kerja yang kompleks akan menghasilkan tipe solidaritas organik. Secara singkat, solidaritas mekanik berbentuk karena adanya saling kesamaan 
antaranggota masyarakat, yang dimaksud dengan kesamaan antar anggota masyarakat bisa dilihat dari tujuan masyarakat itu sendiri dan adat yang mereka biasa lakukan sehingga dapat tercipta solidaritas sedangkan solidaritas organik lebih terbentuk karena adanya perbedaan antaranggota masyarakat. Perbedaan jenis pekerjaan, pemikiran dan gaya hidup orang kota menyebabkan terciptanya solidaritas organik sehingga dengan adanya perbedaan tersebut menyebabkan setiap anggota masyarakat saling bergantung sama lain.

Kedua tipe solidaritas ini memiliki beberapa ciri sebagaimana dijelaskan Durkheim.

1) Anggota masyarakat dengan tingkat pembagian kerja yang rendah (solidaritas mekanik), masih terikat satu sama lain atas dasar kesamaan emosional dan kepercayaan, serta adanya komitmen moral. Perbedaan adalah sesuatu yang harus dihindari. Pada masyarakat dengan tingkat pembagian kerja yang tinggi (solidaritas organik), sangat memungkinkan terjadi perbedaan, dan masyarakat disatukan oleh saling ketergantungan fungsional.

2) Solidaritas mekanik didasarkan pada kesadaran kolektif yang kuat, anggota masyarakat diharapkan mampu mempertahankan kesamaan, sedangkan solidaritas organik, otonomi individu sangat dihargai mengingat setiap individu menjalankan fungsi yang berbeda-beda.

3) Dari segi kontrol sosial, dalam solidaritas mekanik, nilai dan norma bersifat umum dan abstrak, hukum yang berlaku lebih bersifat represif. Hukuman diberlakukan hanya sematamata agar pelanggar hukum jera dan mendapat hukuman yang sebanding dengan pelanggarannya. Pada solidaritas organik, hukum lebih bersifat restitutif, maksudnya hukum diberlakukan hanya semata-mata untuk mengembalikan masyarakat pada kondisi semula. Hukuman diberikan oleh individu yang memang diberi tugas untuk melakukan kontrol sosial.

Merujuk pada konsep solidaritas social yang disampaikan oleh Durkheim, solidaritas sosial kemasyarakatan yang ada di Desa Pamong termasuk kategori tipe solidaritas sosial mekanik. Persamaan emosional sebagai warga desa Pamong masih terjalin dengan baik meskipun terjadi beberapa kali perubahan kepemimpinan desa. Bercirikan masyarakat sector pertanian dengan nuansa islami yang begitu kental, masih mudah bagi pemerintah desa atau tokoh masyarakat untuk selalu mempertahankan dan memperkuat rasa solidaritas sosial di antara msyarakat. Bentuk solidaritas sosial yang selama ini terjadi di Desa Pamong adalah pengajian untuk laki-laki yang dilakukan pada kamis malam secara bergiliran dari satu RT ke RT berikutnya, sedangkan pengajian untuk perempuan dilakukan pada hari minggu. Bentuk solidaritas sosial lainnya adalah masih dipertahankannya budaya "plerek" yaitu pengumpulan bantuan dari masyarakat yang dapat berupa beras $1-2$ liter, uang tunai maupun bahan makanan lainnya. Hasil plerek dikumpulkan pada tiap RT untuk kemudian digunakan ketika ada warga masyarakat yang mengalami musibah (meninggal dunia atau sakit). Kepala desa selalu berupaya 
mempertahankan bentuk bentuk solidaritas sosial masyarakat yang selama ini sudah berjalan di Desa Pamong.

Kepala desa Pamong menyadari bahwa peran seorang pemimpin dalam menumbuhkan semangat gotong royong dan solidaritas social diawali dari bagaimana gaya kepemimpinan kepala desa. Kepemimpinan adalah kemampuan dan kepribadian seseorang dalam mempengaruhi serta membujuk pihak lain agar melakukan Tindakan pencapaian tujuan Bersama. Kepemimpinan berfungsi memandu, menuntun, membimbing, membangun serta menjalin jaringan komunikasi yang baik. Oleh karena itu, kepala Desa merutinkan agenda program kerja jumasih atau jumat bersih pada minggu ketiga setiap bulannya dan mengaktifkan kembali gotong royong antar warga yang dilakukan secara bergiliran pada minggu kedua di tiap lingkungan RT/RW. Berikut ini strategi yang dilakukan oleh kepala desa dalam menumbuhkan dan memperkuat solidaritas social kemasyarakatan di Desa Pamong : a. servant/pelayan ; memberikan pelayanan kepada anak buahnya untuk mencari dan membimbing menjuju kebaikan; b) guardian/penjaga; menjaga komunitas dan tekanan; c) pathfinding yaitu menentukan visi dan misi organisasi pemerintahan desa; d) penyelaras yaitu menentukan bahwa struktur, system dan proses operasional organisasi memberikan dukungan pencapaian visi dan misi serta e) pemberdaya yaitu kepala desa mampu menggerakkan semangat dalam diri orangorang, kreativitas, bakat dan kecerdikan.

\section{KESIMPULAN}

Solidaritas sosial kemasyarakat di Desa Pamong termasuk kategori solidaritas sosial mekanik dimana bentuk bentuk kebersamaan yang selama ini terjalin diantara masyarakat masih berjalan dengan baik, meskipun ada beberapa kebiasan masyarakat yang mengalami pergeseran seiring dengan mobilitas masyarakat Desa Pamong yang bekerja sebagai buruh migran di Jakarta.

\section{UCAPAN TERIMA KASIH}

Penulis mengucapkan terima kasih kepada Kepala Desa Pamong beserta jajarannya, Badan Permusyawaratan Desa Pamong, Kader pemberdayaan masyarakat desa dan masyarakat Desa Pamong Kecamatan Ciruas Kabupaten Serang yang telah meluangkan waktu dan menyediakan tempat demi terselenggaranya kegiatan pengabdian kepada masyarakat FISIP Untirta. 
ISSN : :2686-6447

Jurnal ABDIKARYA

E-ISSN : 2715-6605

Volume 3, No. 1, April 2021

\section{DAFTAR PUSTAKA}

Data Monografi Desa Pamong 2019.

Fisip UGM. (2019). Serial Diskusi 4. Bangkitnya Solidaritas Sosial di Tengah Bencana Covid19. Yogyakarta, 13 April 2019

Https://www.cnbcindonesia.com/news/20200411213043-4-151261/15-juta-masyarakat-rikehilangan-pekerjaan-karena-covid-19

Jones. (2009). Pengantar Teori - Teori Sosial: Jakarta: Yayasan Obor.

Nutsani Soyomukti. Pengantar Sosiologi; Dasar Analisis, Teori dan Pendekatan Menuju Analisis Masalah-masalah Sosial, Perubahan Sosial dan Kajian-kajian strategis. http://digilib.uinsby.ac.id/18233/5/Bab\%202.pdf 